\title{
The Effect of Pre-Slaughter Resting Time on the Quality of Pork Meat
}

\author{
Claudiu SIMA ${ }^{1)}$, Lourens HERES ${ }^{2)}$, Ronald KLONT ${ }^{2)}$, Vioara MIRESAN*1) \\ ${ }^{1)}$ University of Agricultural Sciences and Veterinary Medicine Cluj-Napoca, Faculty of Animal Science \\ and Biotechnologies, 400372, Cluj-Napoca, Manastur, 3-5, Romania \\ ${ }^{2)}$ VION food Group, 5281 RM, Boxtel, Boseind 10, The Netherlands \\ *Corresponding author, email: vmiresan@yahoo.com
}

Bulletin UASVM Animal Science and Biotechnologies 72(1) / 2015

Print ISSN 1843-5262; Electronic ISSN 1843-536X

DOI:10.15835/buasvmcn-asb:11125

\begin{abstract}
The quality of meat products strongly depends on fresh meat quality, which is the result of ante-mortem and post-mortem muscle metabolism, influenced by a series of factors. This study was conducted to investigate the influence on the final pork meat quality of different time periods spent by the living swine in the slaughterhouse prior to slaughtering. In the slaughterhouse, a total of 160 pigs were randomly chosen and divided into 2 mixed groups (males and females). The 83 animals in group A were slaughtered on arrival, while the 77 in group B had a period of 3 hours' resting time. Fresh meat quality measurements ( $\mathrm{pH}, \mathrm{L}^{*}$ value, drip loss) were performed on loins and hams for both groups. $\mathrm{pH}$ was measured on loin and ham muscles 45 minutes post mortem in-line at $36^{\circ} \mathrm{C}$ and in the cooling area 24 hours post mortem at $4^{\circ} \mathrm{C}$. Minolta colour $\mathrm{L}^{*}$ value and drip loss for the loin muscles were measured 48 hours post mortem. A slice ca. $2 \mathrm{~cm}$ thick was taken from the Longissimus dorsi at the shoulder side and placed in consumer retail trays for the determination of drip loss and colour L* value. Parametric data were analyzed using ANOVA for both group A and B. There was a significant difference $(\mathrm{p}<0.05)$ for: $\mathrm{pH} 45$ minutes measured in hams, ultimate $\mathrm{pH}$ measured in loins, colour $\mathrm{L}^{*}$ and drip loss. For ultimate $\mathrm{pH}$ measured in hams the differences between the groups were not statistically significant ( $p>0.05$ ). According to the parameters investigated, the pigs with higher pre-slaughter resting time had a darker meat colour, a slower $\mathrm{pH}$ decline and a higher ultimate $\mathrm{pH}$ compared with the animals slaughter directly.
\end{abstract}

Keywords: Colour, drip-loss, pH, pork, pre-slaughtering

\section{INTRODUCTION}

The consumer is increasingly putting value on the quality of meat products, which drives meat producers and processors to do the same (Reynolds-Zayak, 2004). The producers and processors of fresh pork meat are focusing more and more on the ability to increase and standardize the quality and the production yields of the meat products. The quality of meat products strongly depends on fresh meat quality, which is the result of ante-mortem and post-mortem muscle metabolism, influenced by farm management conditions, transport, pre-slaughter handling and resting time, stunning method, processing and cooling conditions of carcasses (Rosenvold and Anderson, 2003).

This study is analyzing the influence of different pre-slaughter resting times on the final pork meat quality in large industrial slaughter plants.

A survey of five slaughter plants carried out in the early 1980s (Warriss and Bevis, 1986) showed that lairage times could vary from less than one hour to more than 20 hours. On average, $46 \%$ of the pigs were killed after up to two hours in lairage, and $63 \%$ were killed within four hours, but $28 \%$ were held for 14 hours or longer. There was a tendency for pigs that had travelled long 
distances to be kept in lairage for longer time. The larger slaughterhouses kept a greater proportion of their throughput overnight before slaughter the next day. Over the last 15 years, this situation changed and the number of slaughter plants has diminished considerably. Nowadays, a high percentage of the total pig production is killed in large plants operating at high line speeds (Warriss, 2000).

Pre-slaughter handling has significant consequences on animal welfare influencing their behaviour and the handling conditions. The major effects of pre-slaughter handling on meat quality are the deviant colour, lower water-holding capacity described by pale, soft, exudative (PSE) and dark, firm, dry (DFD) meat. Of all the preslaughter factors investigated until now, lairage time plays an important role in defining the final meat quality (Nanni et al., 2002).

Creating a small stock in the stables gives the slaughter plants a buffer time which allows them to predetermine the slaughter line speed. However, if the animals were not stressed during transport and unloading, resting them too long can also result in a DFD meat. Long resting time may lead to a loss in production yields and a poor meat hygiene (Warriss, 1987). On the other hand, too short resting time can also decrease meat quality giving the meat an undesirable aspect (PSE). An optimal lairage time is probably between one and three hours. There is sound evidence that allowing the pigs to rest for minimum one hour can have beneficial results on reducing pre-slaughter stress and improving meat quality (Warriss, 2003). The need for coercion will be reduced and the stunning procedures are likely to be controlled more precisely (Warriss, 1987).

There have been several studies that analysed the optimal lairage time for pigs due to its importance in influencing directly meat quality and the processing yields for large slaughter plants, but there is no specified general lairage time yet.

The aim of this study is to analyse the influence of pre-slaughter resting time on the pork meat quality.

\section{MATERIALS AND METHODS}

A total of 160 crossbred pigs were chosen from a random supplier and transported to a slaughter plant in The Netherlands. The transport time was ca. 3 hours and 45 minutes. Upon arrival, the pigs were directly unloaded and divided in 2 mixed groups (males and females). The animals from both groups were unloaded without using any external motivation. Group A (83 animals) were directly slaughtered (on arrival), while Group B, (77 animals) had a 3-hour resting time before the slaughter process. The animals from group $B$ were detained on a lairage temperature of $16^{\circ} \mathrm{C}$ with water showers.

The stunning method used in the slaughterhouse was with $\mathrm{CO}_{2}$ with a concentration of $94-96 \%$. The slaughter weight of the pigs was ca. 125 kilograms. After the stunning, stabbing and bleeding process, the pigs were held in a water bath for 8 minutes at $59.5^{\circ} \mathrm{C}$ to ease the hair removal process and muscle relaxation. Inside the clean slaughter line, fresh meat quality measurements $\left(\mathrm{pH}, \mathrm{L}^{*}\right.$ value, drip loss \%) were performed on loins and hams in both groups. pH measurements (MPI pH-Meter, Meat Probes, Inc.) were performed on loin and ham muscles 45 minutes post mortem in-line at $36^{\circ} \mathrm{C}$ and in the cooling area 24 hours post mortem at $2-4^{\circ} \mathrm{C}$. Minolta colour L* value (Chroma Meter CR-400, Konica Minolta Sensing, Inc.) and drip loss \% in loin muscles were measured, according to Kapper et al. (2012), 48 hours post mortem. A slice of ca. 2 $\mathrm{cm}$ thickness was taken from the Longissimus dorsi (loin) at the shoulder side and placed in consumer retail trays for the determination of drip loss \% and colour $\mathrm{L}^{*}$ value.

Differences in colour, $\mathrm{pH}$ and drip loss values of fresh pork meat are good indicators of good or poor meat quality and are used to define and asses the influence of different lairage times on formed groups $\mathrm{A}$ and $\mathrm{B}$. The mean values for $\mathrm{pH} 45$ minutes measured on hams, ultimate $\mathrm{pH}$ measured on hams and loins, colour $\mathrm{L}^{*}$ value, and drip-loss 48 hours were compared with ANOVA and contrasts were tested with an LSD-test.

\section{RESULTS AND DISCUSSION}

The predictive capability of $\mathrm{pH}, \mathrm{L}^{*}$ value and drip loss in the fresh hams and loins was assessed for both groups (A, B). Table 1 shows the results for the ultimate $\mathrm{pH}, \mathrm{pH} 45$, drip loss and colour $\mathrm{L}^{*}$ value during the slaughter and cooling processes.

Post mortem, the animals in Group B compared with the ones in Group A had a higher average $\mathrm{pH}$ 45 minutes measured on hams $(6.50 \pm 0.05),(P=$ 
0.01 ) and a higher average ultimate $\mathrm{pH}$ measured in loins (5.64 \pm 0.01$),(P=0.01)$. Averaged colour $L^{*}$ value measurements 48 hours post mortem had a lower value for Group B (50.2 \pm 0.45$)(P=0.009)$ compared with Group A (52.3 \pm 0.43$)$. For ultimate $\mathrm{pH}$ measured in hams, the differences between the groups were not statistically significant $(p>0.05)$, although there is a trend (Fig.1) that shows the hams belonging to group B had a higher average ultimate $\mathrm{pH}$. The drip loss measurements for loins showed significant differences $(\mathrm{p}<0.05)$ between groups A and B. Group A without resting time had
$0.19 \%$ more drip loss and a lower WHC compared with the animals from the second Group B (Tab.1).

The results are in agreement with other studies (Nanni et al., 2002) where the meat from the animals with a higher ante mortem stress before the slaughter process had a lower $\mathrm{pH}$, a pale colour and higher drip loss. This situation is caused by the metabolism speed, which increases the protein denaturation, causing PSE meat.

The quantity of glycogen in the muscles decreases during resting, and pigs with less

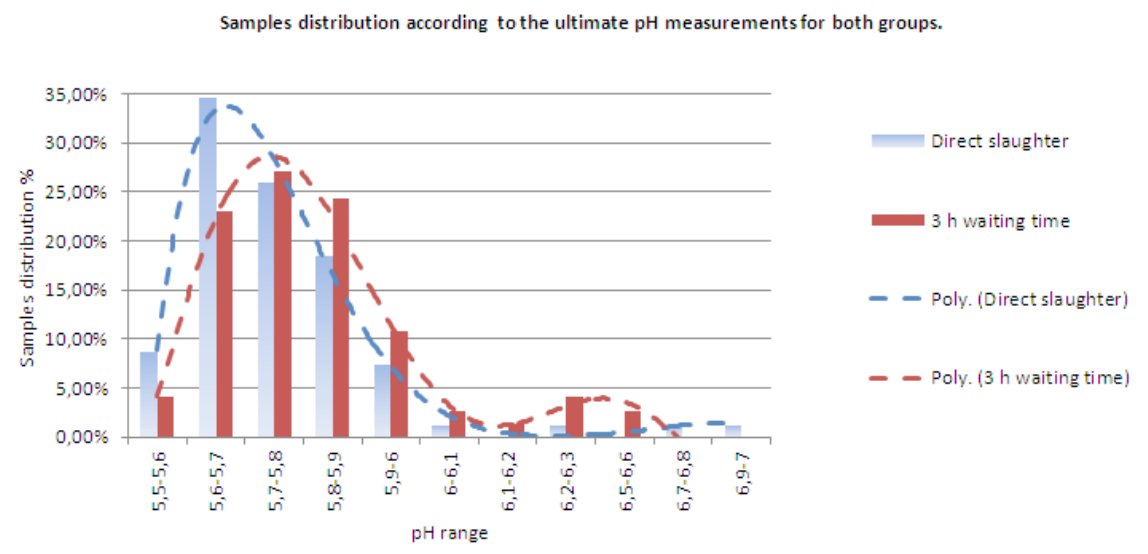

Fig.1 Ultimate pH ham (24 h) direct slaughtered versus $3 \mathrm{~h}$ waiting time

Tab. 1 Average values (SD) of group A and B for $\mathrm{pH}$, colour and drip loss

\begin{tabular}{|c|c|c|c|c|c|}
\hline \multicolumn{6}{|c|}{ Comparation between average groups (SD) for $\mathrm{pH}$, drip loss and colour } \\
\hline & $\mathrm{Ph} 24 \mathrm{~h}$ & Sampels nr. & Direct slaughterd (A) & 3h waiting time (B) & Stat. significance \\
\hline \multirow{3}{*}{ Ph 24 h } & Loin all & 155 & $5,76(0,02)$ & $5,82(0,01)$ & NS \\
\hline & Loin gelts & 100 & $5,78(0,03)$ & $5,79(0,03)$ & NS \\
\hline & Loin boars & 55 & $5,75(0,02)$ & $5,89(0,04)$ & $*$ \\
\hline \multirow{3}{*}{$\begin{array}{c}\text { Ph } 45 \\
\text { minutes }\end{array}$} & Loin all & 79 & $6,33(0,05)$ & $6,50(0,05)$ & $*$ \\
\hline & Loin gelts & 53 & $6,34(0,06)$ & $6,55(0,05)$ & $* *$ \\
\hline & Loin boars & 26 & $6,331(0,09)$ & $6,40(0,1)$ & NS \\
\hline \multirow{3}{*}{ Ph 24 h } & Loin all & 159 & $5,61(0,01)$ & $5,64(0,01)$ & $*$ \\
\hline & Loin gelts & 102 & $5,62(0,01)$ & $5,64(0,01)$ & NS \\
\hline & Loin boars & 57 & $5,59(0,01)$ & $5,63(0,01)$ & NS \\
\hline \multirow{3}{*}{ drip loss } & Loin all & 151 & $1,41(0,09)$ & $1,22(0,09)$ & $*$ \\
\hline & Loin gelts & 49 & $1,34(0,10)$ & $1,24(0,10)$ & $*$ \\
\hline & Loin boars & 84 & $1,50(0,17)$ & $1,18(0,2)$ & $*$ \\
\hline \multirow{3}{*}{$\begin{array}{l}\text { Colour } \\
\text { L-value }\end{array}$} & Loin all & 83 & $52,3(0,43)$ & $50,2(0,45)$ & $* * *$ \\
\hline & Loin gelts & 49 & $51,6(0,53)$ & $50,2(0,51)$ & $* *$ \\
\hline & Loin boars & 34 & $53,2(0,72)$ & $50,1(0,87)$ & NS \\
\hline
\end{tabular}




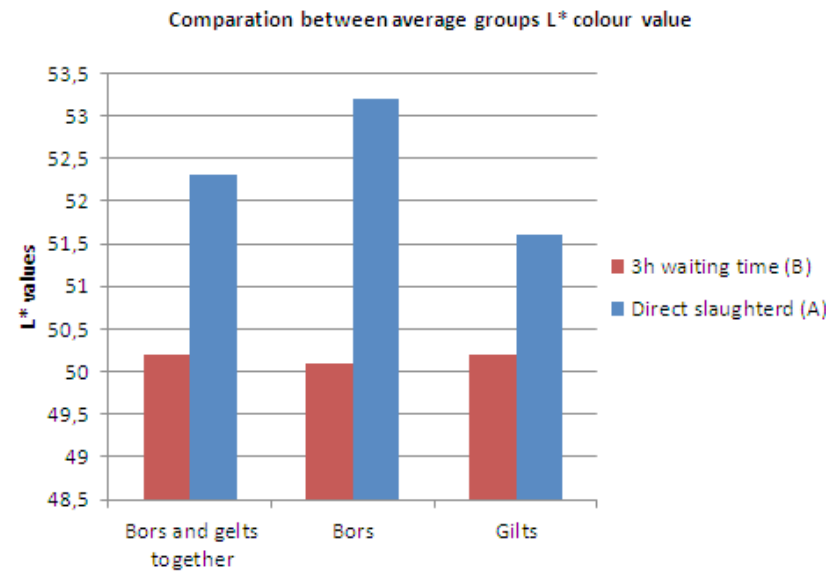

Fig. 2 Comparison between average values group A and B , Minolta $\mathrm{L}^{*}$ value for boars and gilts

glycogen in their muscles, like the ones from group $\mathrm{A}$, will result in a higher ultimate $\mathrm{pH}$ in the meat.

The colour L* parameter shows that the meat from group A had a lighter colour (Fig. 2). These results are similar to those found by Garnier et al., (2003), showing that stressed pigs have as result a lower $\mathrm{pH}$ and paler meat. Resting the animals a longer period in the lairage can have beneficial results mainly in terms of reduced drip loss, a higher initial pH, less pale muscles (lower $\mathrm{L}^{*}$ values) and less PSE meat. Giving the animals a resting period may result in higher meat quality for the producers and processors of pork meat and meat products.

The high variability in the outcomes, as seen in the estimated standard deviations for the average $\mathrm{pH}$ and drip loss, underlines that there are animals from group A that had nevertheless high $\mathrm{pH}$ and low drip loss. This situation may be caused by measuring bias, as measuring $\mathrm{pH}$ in meat is not a very robust method and is vulnerable to errors. Some of the variables influencing meat $\mathrm{pH}$ and drip loss measurements are: type of device used, number of measurements between every calibration of the pH-meter and weighing scale. Nevertheless, all three parameters measured showed statistically significant differences between the two groups, A and B.

\section{CONCLUSIONS}

The results of the present study have demonstrated that longer periods in lairage show beneficial results mainly in terms of reduced drip loss, a higher initial $\mathrm{pH}$, less pale muscles (lower $\mathrm{L}^{*}$ values) and less PSE meat.

The animals with a pre-slaughter resting time had darker meat colour, a slower $\mathrm{pH}$ decline, a higher ultimate $\mathrm{pH}$ and a higher WHC compared with the ones slaughter directly.

\section{REFERENCES}

1. Garnier JP, Klont R, Plastow G (2003). The potential impact of current animal research on the meat industry and consumer attitudes towards meat. Meat science. 63(1):79-88.

2. Kapper C, Klont R E, Williams P C, Urlings HAP (2012). Prediction of pork quality with near infrared spectroscopy (NIRS); 2. Feasibility and robustness of NIRS measurements under production plant conditions. Meat Science, 91(3), 294-299.

3. Nanni Costa L, Lo Fiego DP, Dall'olio S, Davoli R, Russo V. (2002). Combined effects of pre-slaughter treatments and lairage time on carcass and meat quality in pigs of different halothane genotype. Meat Science 61, 41-47.

4. Reynolds-Zayak L. (2004) Understanding consumer's trends can present new opportunities. Agri-Processing Branch Business \& Inovation Alberta Agriculture Food and Rural Development.

5. Rosenvold K, Andersen H (2003). Factors of significance for pork quality - A Review. Meat Science. 64:219-237.

6. Warriss P D, BEVIS EA (1986) Transport and lairage times in British slaughter pigs. British Veterinary Journal. 142: 124-130.

7. Warriss PD (1987) Evaluation and Control of Meat Quality in Pigs. 245-264.

8. Warriss PD (2000) Meat Science: An Introductory Text. Wallingford, CAB International. 131-155.

9. Warriss PD (2003). Optimal lairage times and conditions for slaughter pigs: a review;Veterinary Record 153: 170176.

10. Wayne Du. Pork Quality Assurance Program Lead/ OMAFRA April 2001. 